
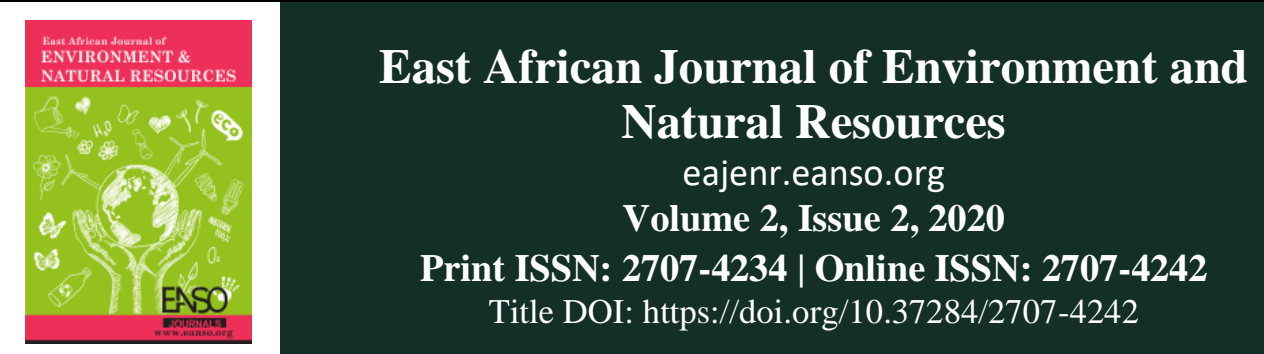

Original Article

\title{
The Trend and the Pattern of Seasonal Rainfall in the Period 1993 - 2018 in Embu East Sub County, Kenya
}

\author{
Linus Mugendi Ireri $^{1 *}$ \\ ${ }^{1}$ Karatina University, P. O. Box 2663-60100, Embu. Kenya. \\ *Correspondence email: irerimuge@gmail.com
}

Article DOI: https://doi.org/10.37284/eajenr.2.2.165

\section{Date Published: ABSTRACT}

11 May 2020 Kenya, like many countries in the world, is vulnerable to climate variability and change. The livelihood of the people in Embu East Sub-county is highly

Keywords: dependent on rain-fed agriculture so climatic threats affect food and animal production. Climate variability has negatively affected mixed crop-livestock

Trend, production. The objective of this study was: to establish the trend in seasonal

Seasonal Rainfall, Period 1993-2018,

Embu East Sub

County. rainfall in the period (1993-2018). The study used a descriptive survey research design guided by the Sustainable Livelihood Approach (SLA) theory. A sample of 364 subjects was composed of 362 heads of farming families and 2 Agricultural Field Officers. Data was obtained through the study of rainfall records in Embu Meteorological Stations, administration of household questionnaires, and interview schedule. The Methods of data analysis and presentation included time-series line graphs to show the trend, frequency tables, and percentages. The coefficient of variation was used to check the homogeneity of March-April-MAY and October-November-December seasons. A paired sample was used to test the hypothesis. The findings established that the rainfall trend was irregular between the years 1993-2018. The onset and the cessation of the MAM and OND varied significantly even though the MAM rainfall was on the upward trend and that of the OND was on the downward trend. The study recommends the following strategies the need to establish more rainfall stations in the study area. Policymakers should build the capacity of the farmers on how to exploit MAM fully and OND seasons and design a more efficient and interactive approach among the climate scientist-decision makers and the farmers to ensure effective communication on rainfall trends and pattern. 
East African Journal of Environment and Natural Resources, Volume 2, Issue 2, 2020

Article DOI: https://doi.org/10.37284/eajenr.2.2.165

\section{APA CITATION}

Ireri, L. (2020). The Trend and the Pattern of Seasonal Rainfall in the Period (1993-2018) in Embu East Sub County, Kenya. East African Journal of Environment and Natural Resources, 2(2), 10-18. https://doi.org/10.37284/eajenr.2.2.165

\section{CHICAGO CITATION}

Ireri, Linus. 2020. "The Trend and the Pattern of Seasonal Rainfall in the Period (1993-2018) in Embu East Sub County, Kenya". East African Journal of Environment and Natural Resources 2 (2), 10-18. https://doi.org/10.37284/eajenr.2.2.165.

\section{HARVARD CITATION}

Ireri, L. (2020) "The Trend and the Pattern of Seasonal Rainfall in the Period (1993-2018) in Embu East Sub County, Kenya”, East African Journal of Environment and Natural Resources, 2(2), pp. 10-18. doi: 10.37284/eajenr.2.2.165.

\section{IEEE CITATION}

L. Ireri, "The Trend and the Pattern of Seasonal Rainfall in the Period (1993-2018) in Embu East Sub County, Kenya", EAJENR, vol. 2, no. 2, pp. 10-18, Jun 2020.

\section{MLA CITATION}

Ireri, Linus. "The Trend and the Pattern of Seasonal Rainfall in the Period (1993-2018) in Embu East Sub County, Kenya". East African Journal of Environment and Natural Resources, Vol. 2, no. 2, Jun 2020, pp. 10-18, doi:10.37284/eajenr.2.2.165.

\section{INTRODUCTION}

The observable effects of global climate change to the environment include drought, the increase in aridity and floods as reported by the Intergovernmental Panel on Climate Change (IPCC, 2014). According to FAO (2007), Africa is prone to climate variability and experiencing the effects of floods and drought. Boyd et al. (2013) noted that unpredictable rainfall patterns in SubSaharan Africa affect national economies and the livelihood of the people who depends on rain-fed agriculture.

Jones and Thornton (2003) note that climate variability and change will cause farming conditions to deteriorate in the entire African continent.

FAO (2015) notes that extreme shocks like drought and floods were the main features of climate in East Africa for a period of seven years from 1996 to 2003. The amount of rainfall during the long rain season (March-April-May) declined with a range of $50-150 \mathrm{~mm}$ per season. The inadequate rainfall affected the yields of slow-maturing crops. Slow maturing crop varieties depend upon rain during the typically wet season, and progressive moisture deficit results in low crop yields in the end, thereby reducing the availability of food supply. Alderman and Haque (2007) report that weather-related risks often determine rural livelihoods and explain why households remain poor.
According to Mateche (2011), The frequency and intensity of drought have been increasing over a long period in Kenya. The impact of drought has been highly felt in arid and semi-arid lands of coastal, Eastern, North Eastern and Rift valley The number of people affected by the famine after the harvest failed due to drought has increased from 16,000 in 1975 to 10 million in 2010. This led to a high demand for relief aid from the government and non-government organizations to cushion the affected human population and their livestock from the effect of drought. Therefore, there is dire need to understand the trend and the pattern of rainfall for the ease of planning by the policymakers and the local farmers

GoK (2014) the variation of rainfall characteristics like drought, cessation, and distribution of the rainfall may reduce the utilization of land, forest, and water resources When the utilization of these resources is affected, there is a disruption of food production in Embu East Sub-county. GoK (2013) report shows that ongoing change in rainfall, seasonal patterns and increased frequency of drought are already complicating people's ability to grow food crops and rear livestock and live healthy lives; the longer-term trends are set to increase the challenge.

Jones and Thornton (2003) found out that extreme weather events have always occurred periodically in rural areas resulting in considerable disruption to rural life. Further, the lack of accurate and timely weather information, greatly hamper farmers' 
ability to respond to the threat of climate variability and change. The government of Kenya and the nongovernmental organizations have been building capacity using location-specific measures for climate change resilience among households (Care International, 2014). Some of the efforts to deal with climate threats include the Water Act 2016, the Forest Management Act 2016, and the National Climate Change Action 2013-2017 (GoK, 2016). These measures cannot be effective without understanding the trend and patterns of rainfall through local institutions like Kenya Meteorological Departments (KMD) that plays an important role in forecasting and circulating climate predictions to help in reducing the negative impact of climate threats (Shilenje \& Ogwang, 2015).

Understanding the trend and patterns of rainfall at the Sub-county is necessary for determining the vulnerability of the households. Embu East Sub County receives high to moderate rainfall, and farmers depend primarily on agriculture for their livelihood (GoK, 2014). It is important therefore to establish the trend and pattern in seasonal rainfall that may aid in the generation of the policies and enable the farmers to make the informed choices on the farming practices at a local scale,

Climate adaptation research has its focus on the impact of climate change on various sectors of the economy. The few researches on impact of climate change have provided an understanding of the trend and pattern of seasonal rainfall at a local scale Locals are unable to meet their food demands because the local farmers rely on rainfed agriculture which is subject to climate variability and in particular rainfall distribution, rainfall amount, cessation, onset and trend. The study established the trend and the pattern of seasonal rainfall in the period (1993-2018) in Embu East Sub-county.

\section{METHODOLOGY}

To determine the trends in rainfall for the period (1993-2018), a descriptive survey design was adopted. The target population constituted of 30,000 farming families in Embu East Sub-county (KNBS, 2009). The accessible population for the study was 3,742 respondents, random sampling technique was used to come up with a sample of 376 subjects which was composed of 374 heads of farming households. In order to obtain pertinent data on rainfall patterns and variability, secondary sources were referred. Rainfall data were obtained from Embu Meteorological Stations through content analysis of unpublished reports for the period 1993 to 2018. To collect the data from the respondents, Structured questionnaires were used. The analyses of the data were done using descriptive and inferential statistics.

\section{RESULTS AND DISCUSSION}

The study results were realized after analyzing the collected data:

\section{The trend in Interannual Rainfall}

The results in Figure 1 present the annual rainfall trend (1993-2018) in the Embu meteorological stations. This analysis was done to establish the rainfall patterns in Embu East Sub-county. The rainfall trends indicate notable changes in rainfall patterns.

The moving average was obtained for a data set from 6 months within a period of 27 years. Though there is an irregular trend, the long term variation in the amount of rainfall seems not to have a major drift from the original. The trend indicates that there was a steep increase in the amount of rainfall received between August 1997 and July 1998; in the same period Kenya received El Nino rains (UNEP, 2009), which is associated with rainfall above normal average and it is followed by a prolonged dry period known as La Nina which is reflected in May 2001 and April 2001.

The peaks are noticed in the year 1993, 1995, 1997 1998, 2002, 2003, 2006, 2007, 2010, 2013, 2015 and 2018 The peaks were as a result of favourable rainfall in the season while the dips are noticed in the year 1993, 1995, 1996, 1999, 2000, 2005, 2008, 2014, 2016 and 2017. The dips were as a result of unfavourable rainfall in the season. Kenya experienced one of the most devastating and severe droughts between 1999-2000. The drought was significant because it caused loss of life of both livestock and people. Despite the huge economic losses, the government incurred high expenditure in cushioning Kenyans against the effects of the 
drought (UNDP et al., 2002). In the year 2014 to 2017, most of the Embu East sub-county experienced normal and below normal average rainfall, which leads to deficiency in moisture content to support agricultural activity. The unpredictable rainfall pattern poses a challenge to farmers when adapting to varying climate. This is well corroborated by a majority of the respondents who reported that the weather pattern is varying. Agriculture in Embu East Sub-County is purely rain-fed, and locals depend on it for survival (GoK, 2013). Unpredictable rainfall pattern has led to a decline in crop and livestock production in the study area.

Figure 1: Rainfall Trend (1993-2018)

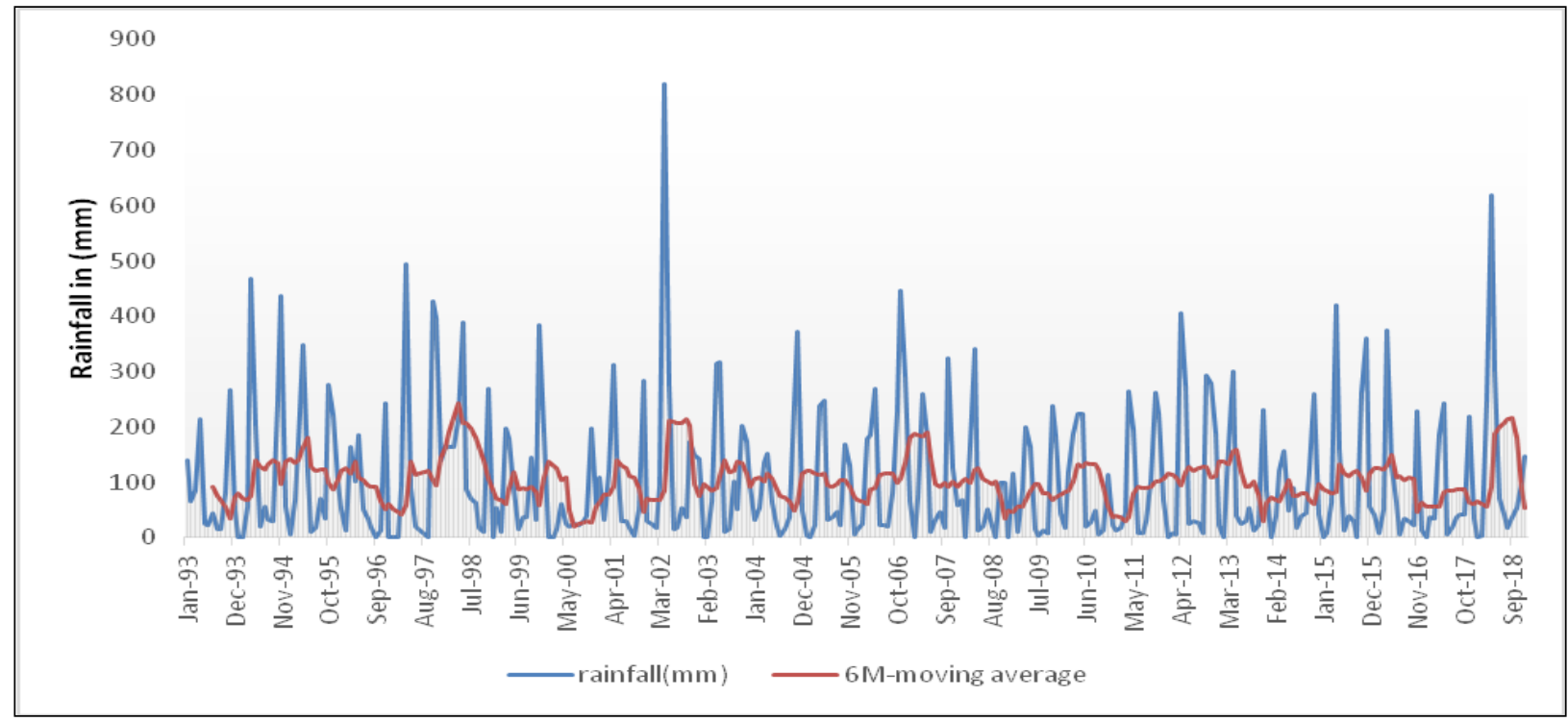

The trend in Seasonal Rainfall. The results in FIGURE 2 present the inter-annual seasonal rainfall for MAM and OND. Analysis of seasonal rainfall shows the comparison of the nature of MarchApril-May and October-November-December seasonal rainfall for a duration of 27 years.

Figure 2: Seasonal Rainfall (March-April-May and October-November-December)

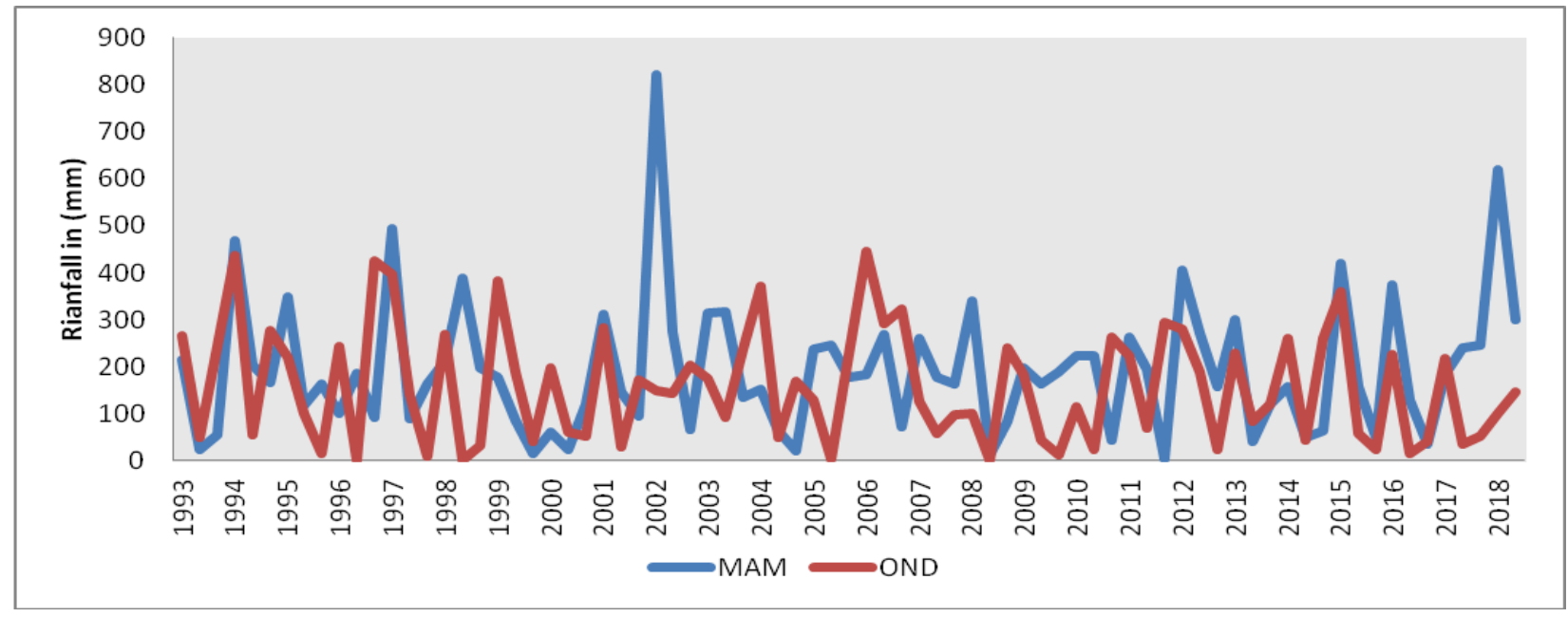

Interannual seasonal rainfall curve indicates that OND was more irregular than MAM and that MAM received more rainfall than the OND.
Table 1 shows the coefficient of variation $(\mathrm{cv})$ of MAM and OND interannual rainfall; $\mathrm{CV}$ is used to measure the homogeneity of the rain seasons. 
Table 1: Results for Coefficient of Variation.

\begin{tabular}{lll}
\hline & MAM & OND \\
\hline Standard deviation & 141.9001 & 119.7275 \\
Mean & 192.765 & 157.754 \\
Coefficient of Variation & 73.613 & 75.897 \\
\hline
\end{tabular}

In Table 1, the coefficient of variation of rainfall within seasons was obtained. During the long rain

Figure 3: Trend for MAM and OND Rainfall

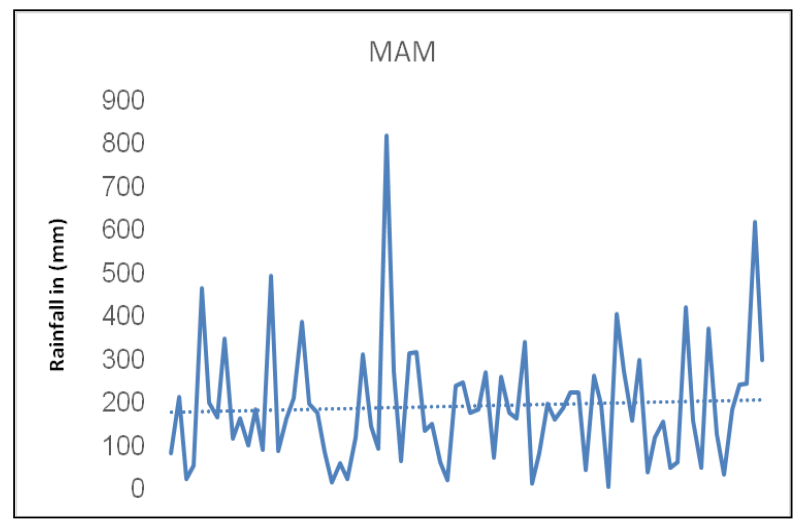

The dotted line is the linear trend obtained by regression. The long rain (MAM) season is more uniform or homogenous, potentially reducing the effect of within-season variability than short rain (OND), which seems to be creating a more irregular pattern. MAM season indicates an increasing trend. Seager, Nalk, and Vogel (2012) reported that the precipitation patterns over East Africa would be enhanced with the warming climate implying that the long rains will too increase. The OND seasons show a downward trend in the amount of precipitation received with the period (1993-2018). If timely planting either prior to or on the onset of the OND is not done the crop might suffer from the shortage of moisture which could lead to low crop production. Recha et al_(2011) noted the main characteristic of OND rainfall is that its distribution from onset to cessation dates is fairly constant with rainfall increasing in early November. The trend indicates irregular rainfall patterns during the OND season, assuming the declining trend in the month of December. To obtain high crop yields farmers would have to plant before or at the onset of the
(MAM), the coefficient of variation was $73.613 \%$, and that of short rains reported a CV of $75.897 \%$. The short rain (OND) had a higher Coefficient of Variation around the mean within seasons than long rains (MAM).

Figure 3 indicates that the trend of OND seasonal is declining, and that of MAM is increasing. If farmers have to realize better yields, they have to optimize rainfall received at the onset of the season, especially OND.

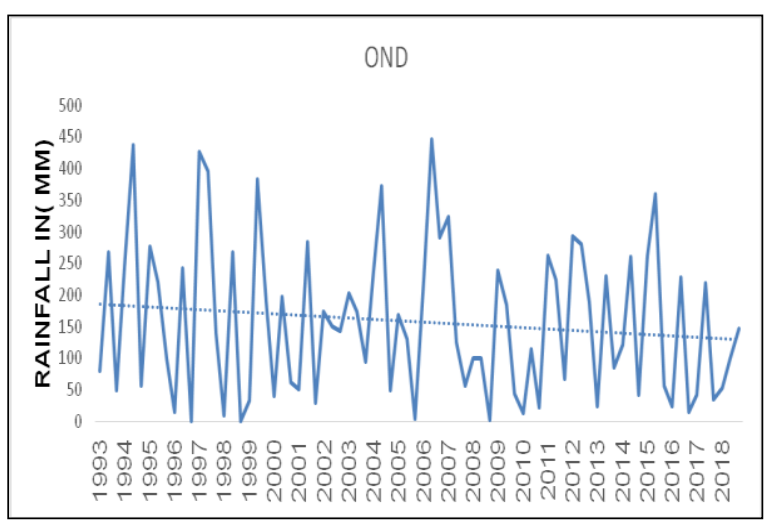

season. According to Hansen (2005), crop production is highly dependent on the distribution of rainfall within the season rather than the seasonal average. It is imperative for the farmers to plant prior or at the onset of the season to avoid losing a significant amount of rainfall, which could affect crop performance.

Knowledge of climate change and variability significantly contributes to adaptation measures that will make the farmers resilient to its threat. The results presented in Table 2 show that most $(53.5 \%)$ the interviewed respondents had noticed evidence of climate change while $62.4 \%$ of the respondents indicated that the rainfall cessation started late, $77.1 \%$ noted that the rainfall amount was light and the $71.8 \%$ had indicated that the rain seasons ended earlier than normal. Most $(65.2 \%)$ of the respondents identified drought as a major climatic event. A majority $(85.1 \%)$ of the interviewee indicated that MAM and OND seasons experienced heavy rainfall at the beginning of the season. 
East African Journal of Environment and Natural Resources, Volume 2, Issue 2, 2020

Article DOI: https://doi.org/10.37284/eajenr.2.2.165

Table 2: Knowledge of Climate Change and Variability

\begin{tabular}{llll}
\hline & & Frequency & Percentage \\
\hline Have you noted any climate & Yes & 197 & $53.5 \%$ \\
Rainfall Onset & No & 171 & $46.5 \%$ \\
\multirow{3}{*}{ Rainfall Amount } & Late & 226 & $62.4 \%$ \\
& Early & 136 & $37.6 \%$ \\
Rainfall Season Distribution & Light & 279 & $77.1 \%$ \\
& Normal & 83 & $22.9 \%$ \\
& Normal & 54 & $14.9 \%$ \\
Cessation & Heavy at the beginning & 308 & $85.1 \%$ \\
& Early & 260 & $71.8 \%$ \\
Major Climatic Events & Normal & 58 & $16.0 \%$ \\
& Late & 44 & $12.2 \%$ \\
& Drought & 236 & $65.2 \%$ \\
& Floods & 87 & $24.0 \%$ \\
\hline
\end{tabular}

Farmer's observations on changes in climate could help appreciate the need to adapt in response to new weather trend. Most of the respondents had regularly experienced drought, delayed onset, early cessation, and light rainfall amount. Moreover, the majority of the interviewed respondent indicated that rainfall was heavy at the beginning of the season. This implies that rainfall was unpredictable during the study period (1993-2018) which point to how difficult it was for the farmers to deal with the uncertainty of weather patterns, thereby challenging farmers' ability to adapt to the varying climate.

Plate 1 shows the maize plants infested by pests in the study area. The armyworm has been a major challenge to maize farmers which has been associated with climate change.

\section{Plate 1: Maize Plants Infested by Army Worms in Kathanjuri, Embu East Sub-County}

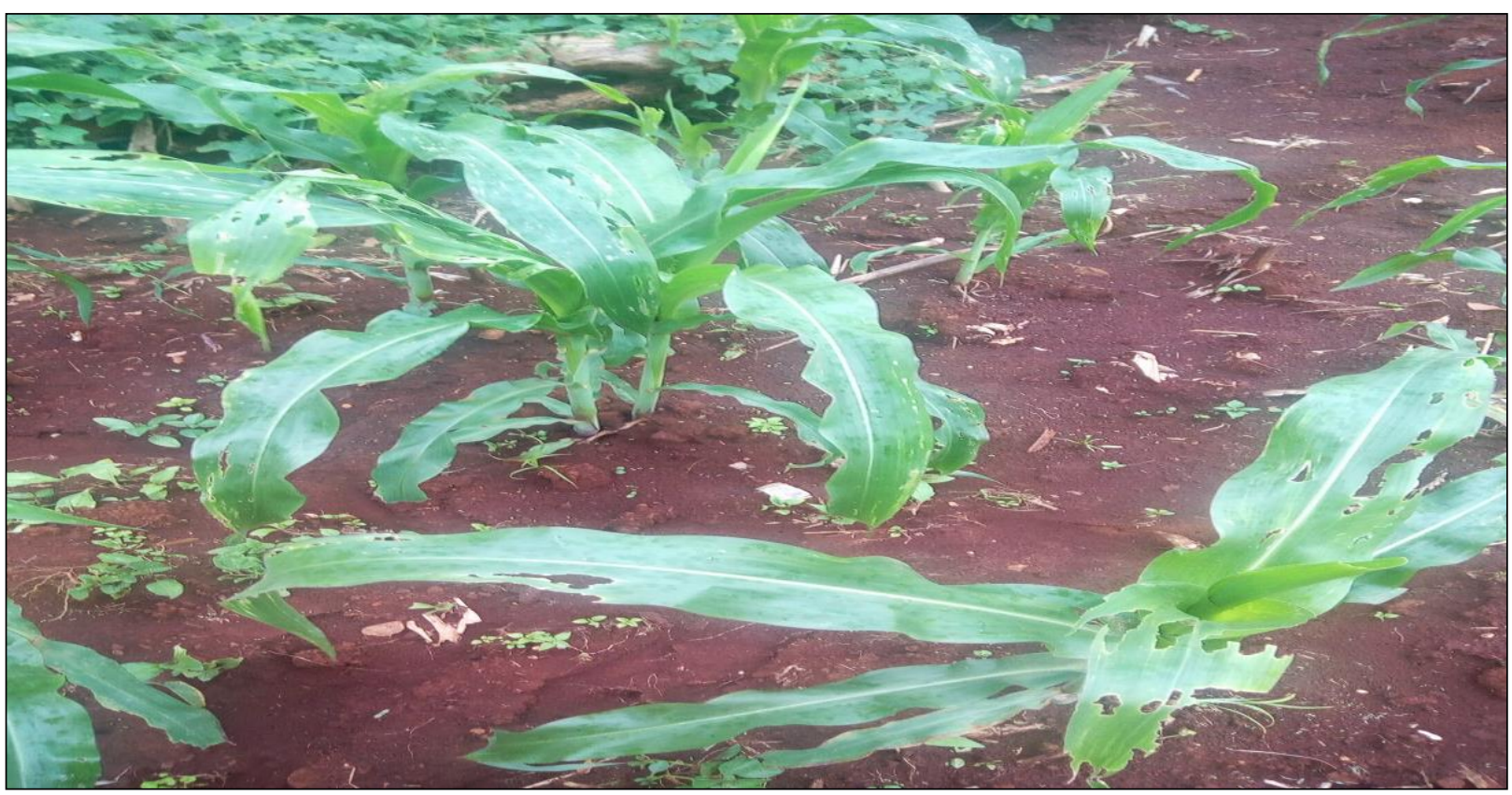


Table 3 presents the chi-square test to establish the relationship between rainfall onset and crop failure shows that p-value .000, df- 3 , and the Alpha value are .05 . The p-value is $.000<.05$; therefore, there is a strong link between rainfall onset and crop failure. If the onset is delayed or if it could come earlier, then it may affect the germination and growth of crops. Table 3 presents the result of the paired sample test for the hypothesis that states that; there is no significant variation between MAM and OND seasonal rainfall.

Table 3: Hypothesis testing Results:

\begin{tabular}{lllll}
\hline 2 Paired Differences & & & \\
\hline Mean & Std. Deviation & Std. Error & \multicolumn{2}{l}{ 95\% Confidence Interval } \\
& & & Lower Limit & Upper Limit \\
\hline 135.0153846 & 169.9030870 & 19.2377363 & -3.2918424 & 73.32
\end{tabular}

The results obtained show that the p-value .073> 0.05 ; hence we reject the alternative hypothesis and accept the null hypothesis. The test implies that the MAM and OND seasons are not independent of each other. Variations in MAM could lead to a variation of the OND season.

\section{CONCLUSION}

In establishing the trend in seasonal rainfall, the study found out that there was a significant change in the rainfall trend. The average annual rainfall for 27 years (1993-2018) shows an irregular trend in rainfall amount with a significant decrease in the year 2005, 2008, 2013, 2014, 2016 and 2017 while an increase was noted in the year 1993, 1995, 19971998, 2002, 2003, and 2007, 2010, 2013, 2015 and 2018. The most $(62 \%)$ of the respondents had observed late-onset, and the majority $(85 \%)$ noted that it rained heavily at the beginning of the seasons. The majority (72\%) of the respondent indicated that the rainfall ended early before the cessation months of May and December respectively, while the rainfall trend portrayed irregular patterns throughout the study period. The researcher tested the hypothesis using two paired sample tests and established that there was no significant relation between MAM and OND rainfall season, which implies that MAM and OND seasons were dependent on each other. That means the amount of rainfall in MAM could affect the rain on the OND seasons.

\section{RECOMMENDATIONS}

The study established the irregular patterns of rainfall. The findings provided the trends from 1993-2018, and the trends of MAM and OND seasons, onset, and cessation and within-season characteristics. The study found out that there was no interdependence between MAM and OND rainfall. MAM indicates an increasing trend, while OND showed a declining trend. Therefore, to make the best use of MAM and OND rainfall seasons and reduce the negative effects of seasonal rainfall variation, farming practices should be guided by accurate seasonal predictions of rainfall onset, cessation, amount, trend and distribution in Embu East Sub-county. The current changes in rainfall variability should lead to the assessment of farmers' adaptation practices against the perceived climatic shocks during MAM and OND rainfall seasons.

\section{ACKNOWLEDGEMENT}

I sincerely thank my academic mentors: Prof. Stephen Kairu Wambugu and Dr. Humphrey Kirimi Ireri. I would like to thank them for their advice, encouragement, and support during the writing period. I also appreciate my wife and my children for they allowed me to spend the family resources for the research. finally I Lastly, but by no means least, I am most grateful to the Almighty God who has been my strength and provider during the study period. 


\section{REFERENCES}

Alderman, H., \& Haque, T. (2007). Insurance against covariate shocks: the role of indexbased insurance in social protection in lowincome countries of Africa. World Bank Working Paper No. 95. African Human Development Series. Washington, DC: World Bank.

Boyd, E., Cornforth, R. J., Lamb, P. J., Tarhule, A., Lélé, M. I., \& Brouder, A. (2013). Building resilience to face recurring environmental crisis in African Sahel. Nature Climate Change, 3 (7), 631-637.

Food and Agricultural Organization (FAO) (2015). Climate-Smart Agriculture, Sourcebook. Rome:

FAO.Available:http;//www.fao.org/docrep/01 8/13325e/i3325e.pdf.

Food and Agriculture Organization (FAO) (2007). Adaptation to climate change Agriculture, forestry, and fisheries: perspective, framework, and priorities. Rome: FAO.

Government of Kenya (GoK). (2014). Agricultural Sector Development Support Program (ADSP). Ministry of Agricultural Livestock and Fisheries, Nairobi. Government Printers.

Government of Kenya (GoK). (2013). National climate change action plan 2013-2017. Nairobi, Kenya: Government Printers.

Government of Kenya (GoK). (2016). National Climate Change Action Plan 2013-2017. Nairobi. Government Printers.

Hansen, W. (2005). Integrating Seasonal Climate Prediction and Agricultural model for Insight into Agricultural Practice, Philosophical Transactions of the Royal Society and B Biological Sciences, 11/29/2005.

IPCC. (2014) Climate Change 2014: Impacts, Adaptation, and Vulnerability. Part A: Global and Sectoral Aspects. Contribution of Working Group II to the Fifth Assessment Report of the Intergovernmental Panel on Climate Change. Field, C.B., V.R. Barros, D.J. Dokken, K.J. Mach, M.D. Mastrandrea, T.E. Bilir, M.
Chatterjee, K.L. Ebi, Y.O. Estrada, R.C. Genova, B. Girma, E.S. Kissel, A.N. Levy, S. MacCracken, P.R. Mastrandrea, and L.L.White (eds.). Cambridge, United Kingdom and New York, NY, USA: Cambridge University Press.

Jones, P., \& Thornton, P. (2003). The Potential impacts of climate change on maize production in Africa and Latin America in 2055. Global Environmental Change, 13, 51-59.

Kenya National Bureau of Statistics (KNBS) (2009). Population and housing census. Nairobi, Kenya: Government printers.

King, S. (2014). Community- based adaptation in practice: A Global Overview of CARE international's Practice of Community -Based Adaptation (CBA) to Climate Change. London, $\mathrm{UK}$ : Care International.

Mateche, D. (2011). Environmental security programme. Nairobi, KE: Institute of Securities Studies.

Recha, C, Makokha, G, Traore, P, Shisanya,C, lodoum, T. and Sako A. (2011). Determination fo Seasonal Rainfall Variability, Onset and Cessation in Semi-arid Tharaka district, Kenya. Theoritical and Applied Climatology, 2011. 108 (3-4) DO 10.10.1007/s00704-011-0544-3

Seager, R., Naik, N., \& Vogel, L. (2012). Does global warming cause intensified interannual hydroclimate variability? Journal of Climate, 25(9), 3355-3372.

Shilenje, Z. W. \& Ogwang, B. A. (2015). The role of Kenya meteorological service in weather early warning in Kenya. International Journal of Atmospheric Sciences, 2015.

UNDP, WMO, GOK, IGAD, and DMCN. (2002). Factoring Weather and Climate Information and Products into Disaster Management Policy, A Contribution to Strategies for Disaster reduction in Kenya. Nairobi. Kenya. $13 \mathrm{http} / / /$ kenyaweb.com/agriculture/ Overview of Agriculture in Kenya, 2000

United Nations Development Programme (UNDP) (2013). Gender and Climate Change. Capacity Development series. Asia and the Pacific. New 
East African Journal of Environment and Natural Resources, Volume 2, Issue 2, 2020

Article DOI: https://doi.org/10.37284/eajenr.2.2.165

York, USA: United Nations Development

Programme.

United Nations Environmental Program (UNEP) (2009). Kenya: Atlas of our changing environment. Division of Early Warning and Assessment (DEWA). Nairobi, Kenya.

World Bank (2012). Business and Law: Removing barriers to economic inclusion. Washington, DC: World Bank. 